\title{
Reproductive biology of the squirrelfish, Holocentrus adscensionis (Osbeck, 1765), caught off the coast of Pernambuco, Brazil
}

\author{
RENATA AKEMI SHINOZAKI-MENDES ${ }^{1}$, FABIO HISSA VIEIRA HAZIN ${ }^{1}$, \\ PAULO GUILHERME DE OLIVEIRA ${ }^{3}$ and FELIPE CORREIA DE CARVALHO ${ }^{1}$ \\ ${ }^{1}$ Laboratório de Oceanografia Pesqueira, Departamento de Pesca e Aqüicultura, Universidade Federal Rural de \\ Pernambuco. Rua Dom Manuel de Medeiros s/n Dois Irmãos CEP 52171900, Recife/PE Brasil. \\ E-mail: renataasm@gmail.com \\ ${ }^{3}$ Universidade Estadual da Bahia, Campus VIII Rua do Gangorra, 503 General Dutra. Paulo Afonso/BA Brasil.
}

\begin{abstract}
SUMMARY: In the present work, specimens of Holocentrus adscensionis, caught off Pernambuco State, northeast Brazil, by small scale artisanal fishing boats, were analyzed with regard to gonad maturation, gonad index, size at first sexual maturity, fecundity, type and time of spawning. Two hundred and three specimens were randomly collected, 102 males and 101 females, resulting in a sex ratio very close to $1: 1$. Size at first sexual maturity was estimated at $14.6 \mathrm{~cm}$ fork length, which is smaller than the most caught size class. Females in final maturation were only recorded from October to March, while the proportion of resting females was the highest in June and July. The seasonal variation of sexual stages, together with the variation of the monthly mean gonad index, with the lowest values for females being recorded from May to July, suggests lower sexual activity for this species during this period of the year, which coincides with winter time. The pattern of ovarian development indicates that spawning is synchronous, with oocytes ripening in more than two groups. It is therefore characterized as a batch spawning. Absolute fecundity ranged from 56274 to 249863 oocytes.
\end{abstract}

Keywords: squirrelfish, Holocentrus adscensionis, reproduction, maturity, teleostei.

RESUMEN: BIOLOGÍA REPRODUCTIVA DEL CANDIL GALLITO HOLOCENTRUS ADSCENSIONIS (OSBECK, 1765) CAPTURADO FRENTE A LAS COSTAS DE PERNAMBUCO, BRASIL. - En el presente estudio se analizó la madurez gonadal, índice gonadosomático, edad de primera madurez, fecundidad y tipo y periodo de puesta de los especimenes de Holocentrus adscensionis, capturados frente al estado de Pernambuco (noreste de Brasil) por pequeños barcos de la flota artesanal. Se tomó una muestra al azar de 203 especimenes, 102 machos y 101 hembras, obteniéndose una relación de sexos próxima a 1:1. Se estimó la edad de primera madurez a los $14.6 \mathrm{~cm}$ de longitud total, menor a la mayoría de tallas capturadas. Hembras en el estadio final de maduración fueron únicamente recolectadas de octubre a marzo, mientras que la más alta proporción de hembras en reposo fue de junio a julio. La variación estacional de estadios sexuales, junto con la variación mensual del índice gonadosomático medio (con los menores valores para las hembras de mayo a julio), sugiere una menor actividad sexual de la especie durante este periodo del año (invierno). El patrón de desarrollo ovárico indica que la puesta está sincronizada con la maduración de los oocitos y tiene lugar en más de dos grupos, siendo pues característica de puestas parciales. La fecundidad absoluta fue de 56274 a 249863 oocitos.

Palabras clave: candil gallito, Holocentrus adscensionis, reproducción, madurez, teleósteos.

\section{INTRODUCTION}

The squirrelfish, Holocentrus adscensionis, a reef species (Woods and Greenfield, 1978), belonging to the family Holocentridae, is very common on the coast of Pernambuco in natural as well as artificial reefs. It shows nocturnal behaviour, evidenced by its large eyes, commonly hiding during the daytime in coral crevices (Greenfield, 1981). Juveniles generally congregate in schools, whilst adults tend 
to be more isolated within well established territories (Carvalho-Filho, 1999).

Occurring from the shallow waters of tide pools to the deeper waters of the continental shelf, the squirrelfish is capable of producing sounds with its swimbladder for intra-specific communication purposes (Carlson and Bass, 2000). It feeds mainly during the night on meroplankton, including crab larvae and shrimp, as well as on juvenile fishes (Beets, 1997).

Although it has a relatively low commercial value, its ecological importance is quite significant. It shows great resilience, being able to survive for many days inside traps, as well as in polluted areas (Wyatt, 1983). Due to its beautiful, bright red colour, it is also often used in aquariums (Robins and Ray, 1986). Off northeast Brazil, the species is frequently caught by artisanal boats fishing with traps, hand lines and gillnets.

The squirrelfish has external reproduction, and spawns all year round in warm regions, but only during summer in colder waters of higher latitudes (Thresher, 1984). It occurs on the western coast of the Atlantic Ocean, from North Carolina (USA) to Bahia (Brazil), including the Gulf of Mexico and the Caribbean (Woods and Greenfield, 1978) and on the eastern Atlantic from Gabon to Ascension Island (Ben-Tuvia, 1990).

The objective of the present work is to study the reproductive biology of the squirrelfish caught by small scale artisanal fishing boats off the coast of Pernambuco, northeast Brazil, including information on gonad maturation, gonad index, size at first sexual maturity, fecundity, and spawning type and time, which is crucial for adequately assessing and managing the exploited stocks.

\section{MATERIAL AND METHODS}

The specimens of squirrelfish examined in the present work were obtained from fish markets located in the cities of Recife (Pina Beach), Olinda and Paulista (Janga Beach) (Fig. 1). They were caught by small scale artisanal fishing boats, which never go beyond the outer limit of the continental shelf, generally fishing from about 4 to 16 nautical miles from the coast in depths ranging from 20 to $50 \mathrm{~m}$. All specimens were sampled immediately after landing, and were then taken to the laboratory in order to minimize deterioration by enzymatic activity. Nevertheless, a few boats stayed up to three days at sea, which resulted in some cases in the fish being poorly conserved.

The fishing grounds are characterized by the presence of rocks or coral reefs around which a large number of fishes tend to assemble. The main fishing gears used are traps, hand-lines and gillnets. The exact location where the examined fish were caught is not available. A total of 203 specimens, 102 males and 101 females, were collected from March 2003 to June 2004 (Table 1).

All specimens were initially measured (fork length and total weight), then eviscerated to collect the gonads, which were weighted and measured. Once the dissection and cleaning process was over, the fish was again weighted in order to verify the gutted weight. All biological samples were initially immersed in $10 \%$ formaldehyde solution for 24 hours, and were then transferred to a $70 \%$ ethanol solution for preservation.

In order to describe the relationship between eviscerated and whole weight, the following model was used:

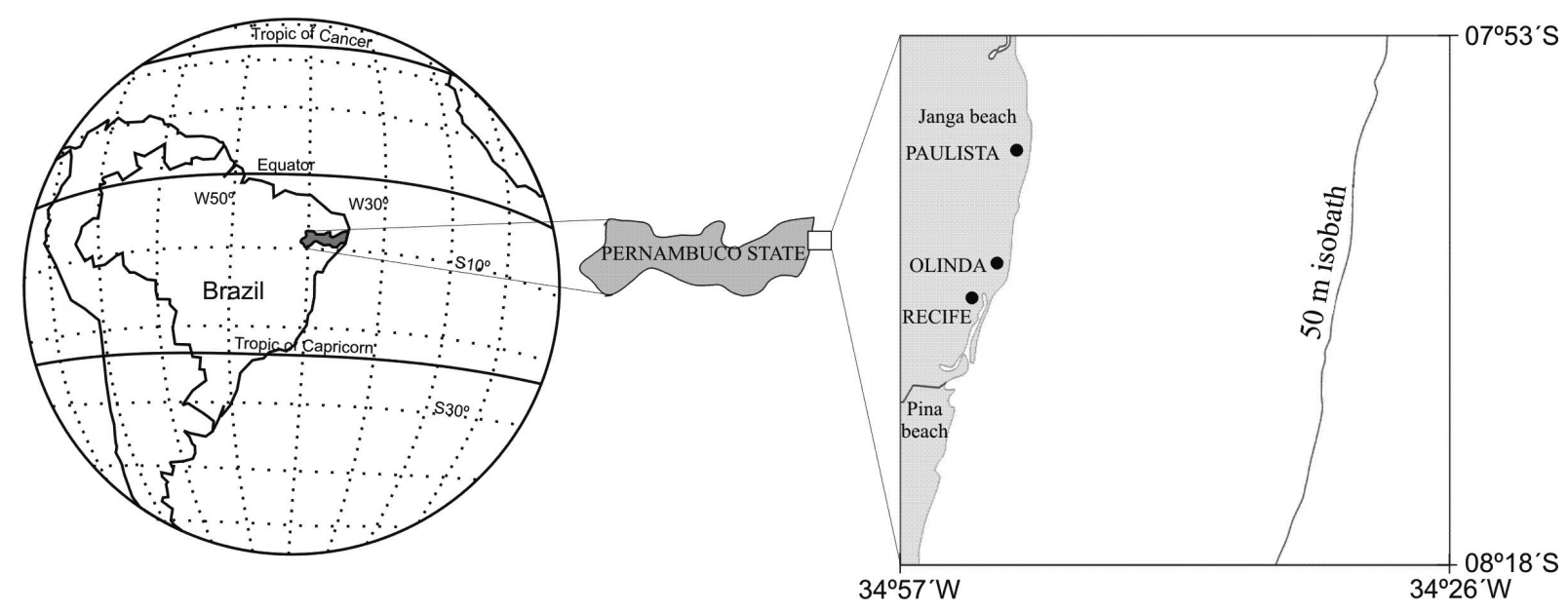

FIG. 1. - Fishing area where the fish sampled were caught on the northeastern coast of Brazil. 
TABLE 1. - Monthly distribution of squirrelfish specimens sampled.

\begin{tabular}{lccc}
\hline Month & Females & Males & Total \\
\hline Jan & 12 & 10 & 22 \\
Feb & 10 & 14 & 24 \\
Mar & 8 & 6 & 14 \\
Apr & 3 & 6 & 9 \\
Mai & 4 & 9 & 13 \\
Jun & 16 & 6 & 22 \\
Jul & 12 & 6 & 18 \\
Aug & 9 & 4 & 13 \\
Sep & 4 & 7 & 14 \\
Oct & 7 & 15 & 14 \\
Nov & 10 & 9 & 25 \\
Dec & 6 & 102 & 15 \\
Total & 101 & & 203 \\
& & & \\
\hline
\end{tabular}

$$
T W=\beta_{0}+\beta_{1} E W+\varepsilon_{i}
$$

where $T W$ is the total weight, and $E W$ the eviscerated weight. In order to describe the relation between weight and fork length, the models used were:

$$
E W=\phi F L^{\theta}+\varepsilon_{i},
$$

for eviscerated weight

$$
T W=\phi F L^{\theta}+\varepsilon_{i}
$$

and for total weight. With a view to evaluate if the $T W-E W$ and $E W-F L$ relationships of males and females showed significant $(\mathrm{p}<0.05)$ differences, a $W$ statistic based on the $\chi^{2}$ distribution was used (Mendes, 1999).

For histological analyses, a small section taken from the middle of the gonad was dehydrated, cleaned, and included in paraffin at $60^{\circ} \mathrm{C}$. The paraffin blocks were then sectioned at $6 \mu \mathrm{m}$, stained with hematoxylin and eosin, and examined under optical microscope. The scale by Vazoller (1996) was used to analyze maturation and gonad development, including the following stages:

\section{Females:}

Immature: ovaries are translucent, with a thin wall. Macroscopic differentiation from testes is not possible.

Maturing: maturing gonads were microscopically differentiated in two different stages: early and late maturation. Gonads in early maturation showed most of the oocytes in the yolk vesicle stage, while females in late maturation showed most of the oocytes in the vitellogenic stage, some with the vitellogenic process already concluded. The ovarian wall thickens.
Mature: the majority of the oocytes in the gonads found at this stage had already completed vitellogenesis. They had a larger volume, and were also well vascularized.

Spent: gonads in this stage had a flaccid aspect and were easily recognized under the microscope, showing several post-ovulatory follicles.

Resting: gonads in this stage were thin, but with a relatively thicker ovarian wall.

\section{Males:}

Immature: without spermatozoa stored in the seminiferous tubules.

Mature: with spermatozoa stored in the seminiferous tubules.

To obtain the spawning time, the monthly mean gonad index was calculated, adapted from Schaeffer and Orange (1956), as follows:

$$
G I=G W \times 10^{5} / F L^{\theta},
$$

where $G I$ is gonad index, $G W$ is gonad weight, $F L$ is fork length and $\theta$ is the allometry coefficient found in the relationship $E W-F L$ for both males and females. To evaluate seasonal variation of the gonad index, the immature specimens were excluded from the analysis.

To analyze spawning type, the maximum diameter of all oocytes whose nucleus was in the central position (i.e. the cells sectioned close to its maximum diameter) was measured for 24 females (4 per sexual stage). The oocyte-diameter frequency distribution was then drawn for each stage and the spawning type classified following Marza (1938): synchronous in one group, synchronous in two groups, synchronous in more than two groups, or asynchronous.

Total fecundity was estimated from 2 pairs of gonads of mature specimens, bimonthly, totalling thus 12 pairs. The gravimetric method proposed by Vazzoler (1996) was used, according to which, the number of vitellogenic oocytes from a gonad section of a known weight are counted and extrapolated to the whole weight of the gonads.

Size at first sexual maturity, as the fork length at which $50 \%$ of the population is able to reproduce, was estimated by the relative frequency of mature specimens in each size class, which was determined by the sigmoid function:

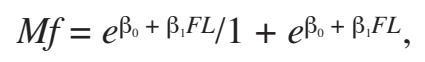




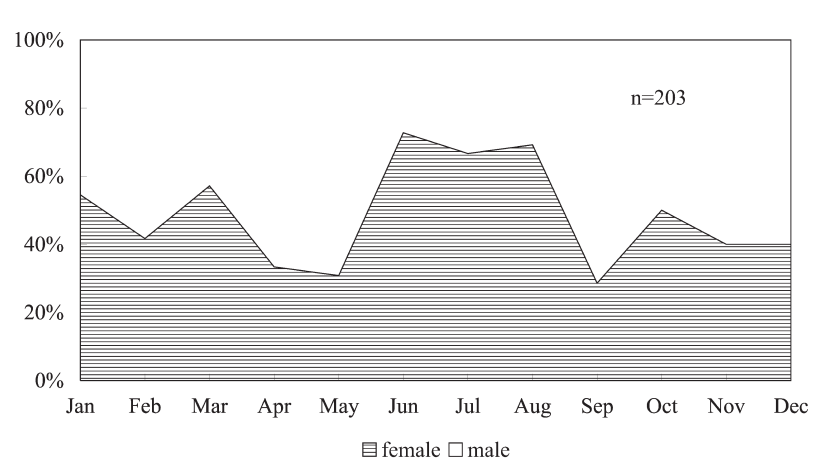

FIG. 2. - Monthly sex ratio of $H$. adscensionis sampled off Pernambuco, Brazil, from March 2003 to June 2004.

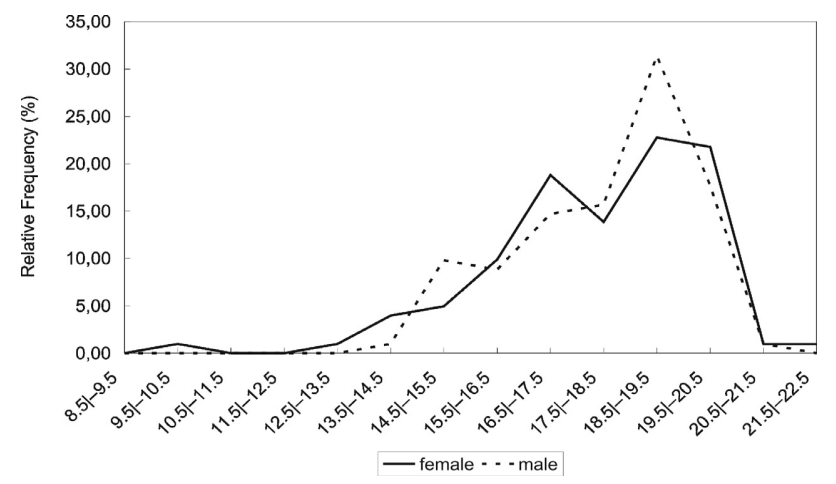

FIG. 3. - Fork-length frequency distribution of H. adscensionis caught off Pernambuco, Brazil.
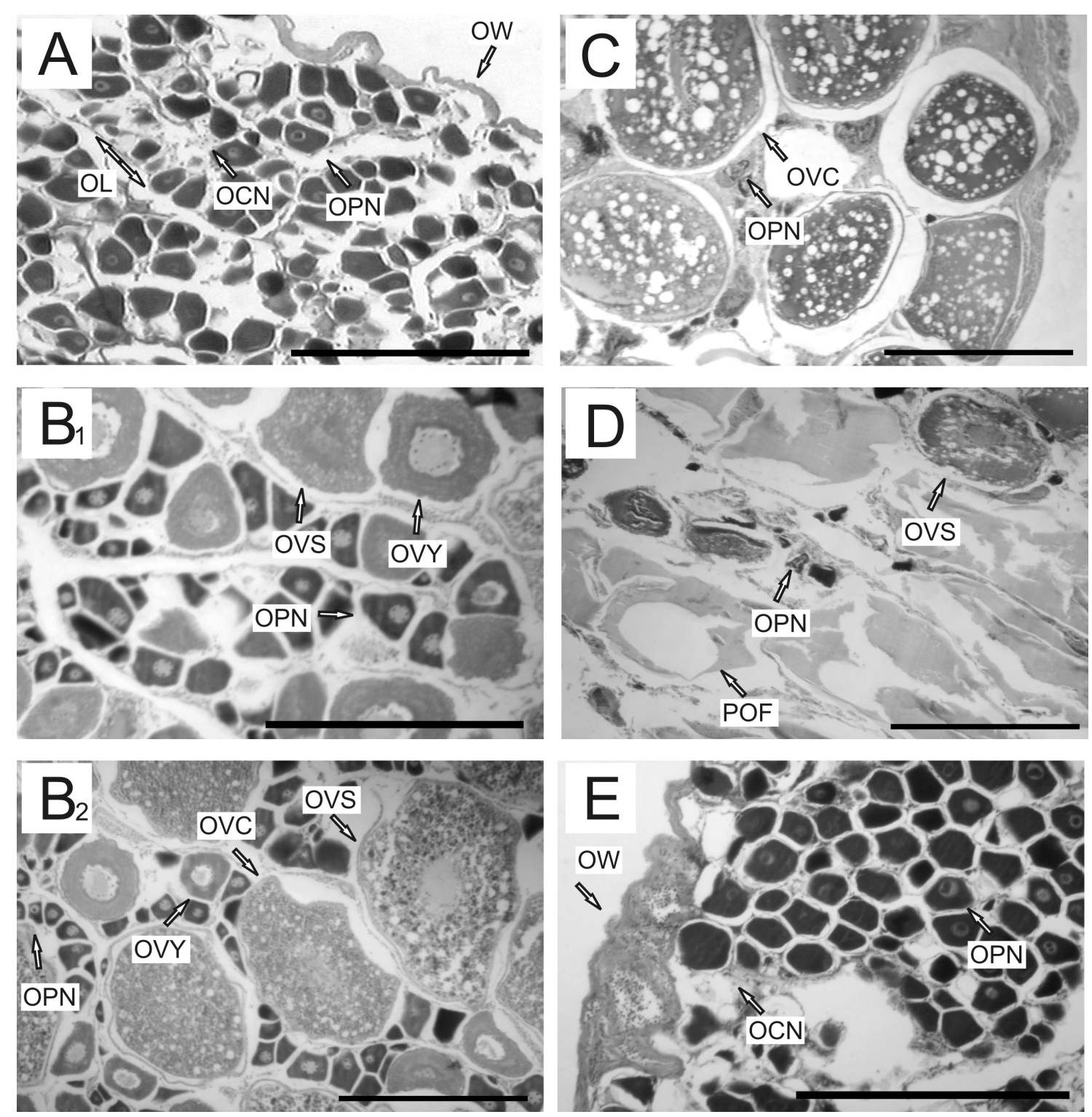

FIG. 4. - Microscopic photographs of H. adscencionis ovaries in different sexual stages. A: Immature, $\mathrm{B}_{1}$ : Early maturation, $\mathrm{B}_{2}$ : Late maturation, C: Mature, D: Spent, E: Resting. OCN: Oocytes in chromatin nucleolus stage, OL: ovigerous lamellae, OPN: Oocytes in perinucleolus stage, OVC: Oocytes with vitellogenesis concluded, OVS: Oocytes in vitellogenic stage; OW: Ovarian wall, OYV: Oocytes in yolk vesicle stage, POF: Post-ovulatory follicles. Staining by hematoxilin/eosin. Scale bar $=250 \mu \mathrm{m}$. 
where $M f$ is the fraction of specimens that are sexually mature.

\section{RESULTS}

The sex ratio of the whole sample was very close to $1: 1$, with a maximum monthly variation of $23 \%$ (Fig. 2). Female fork length ranged from 9.6 to 21.5 $\mathrm{cm}$, with the majority of the examined specimens (77.2\%) lying between 16.5 and $20.5 \mathrm{~cm}$. Male fork length ranged from 13.5 to $20.7 \mathrm{~cm}$, with a mode in the class interval of 18.5 to $19.5 \mathrm{~cm}$ (Fig. 3). Since $E W-T W, E W-F L$ and $T W-F L$ relationships were significantly different between males and females, they were drawn separately for each sex. The relationship between eviscerated $(E W)$ and total weight $(T W)$ was linear, and was expressed by the equation $E W=$ $0.9117 T W+1.7928\left(\mathrm{R}^{2}=0.979\right)$ for males, and $E W$ $=0.9011 T W+1.8591\left(\mathrm{R}^{2}=0.987\right)$ for females. The relationship between Eviscerated Weight and Fork Length was exponential as follows: $E W=$ $0.0889 F L^{2.5074}\left(\mathrm{R}^{2}=0.826\right)$ for males, and $E W=$ $0.0948 F L^{2.4673}\left(\mathrm{R}^{2}=0.878\right)$ for females. Parameter

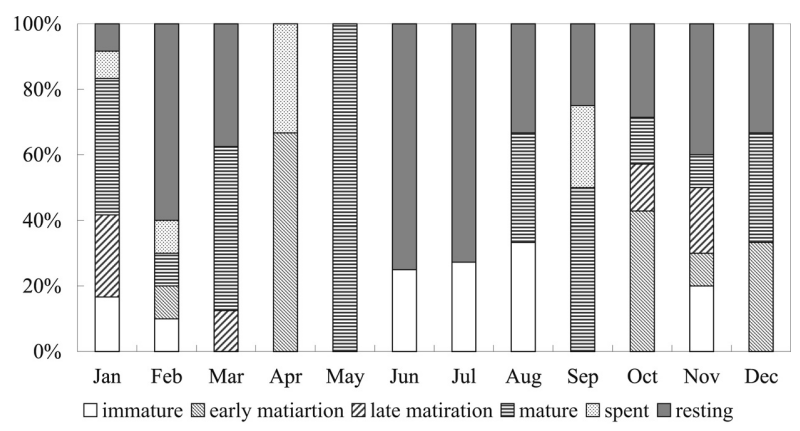

FIG. 5. - Monthly distribution of sexual stages of female H. adscensionis caught off Pernambuco, Brazil.

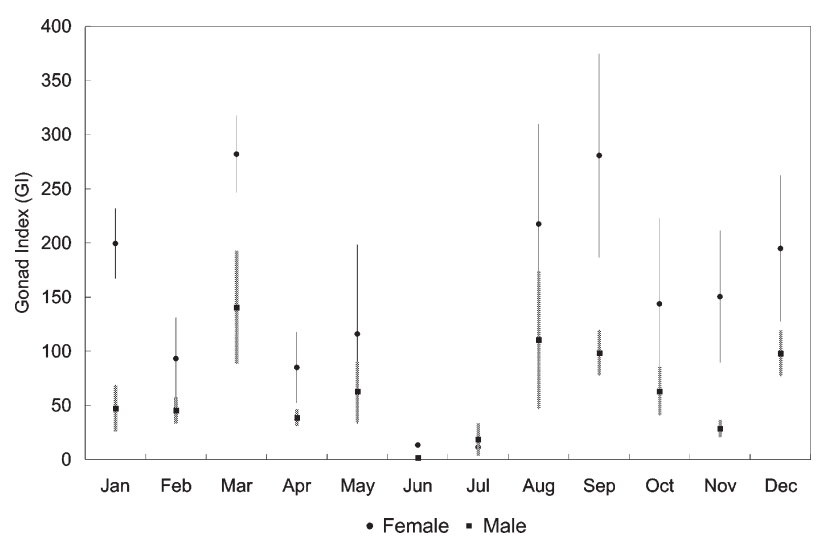

FIG. 6. - Monthly mean gonad index of $H$. adscensionis caught off Pernambuco, Brazil, from March 2003 to June 2004.

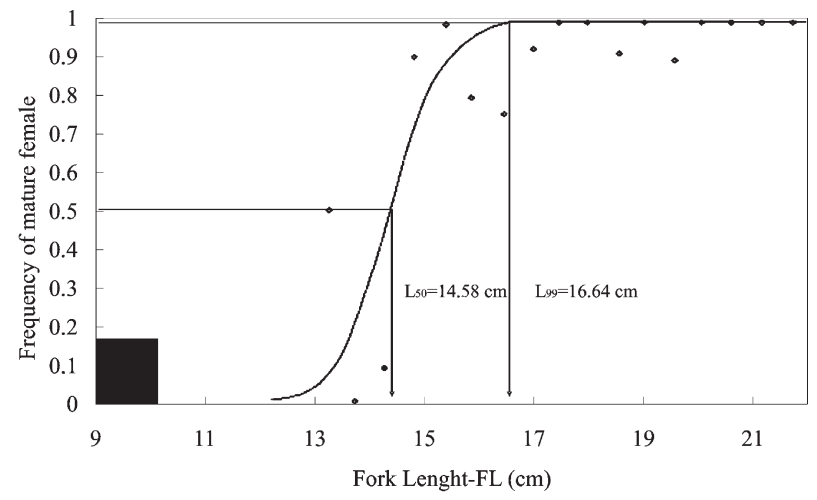

FIG. 7. - Maturation curve of female $H$. adscensionis caught off Pernambuco, Brazil, from March 2003 to June 2004.

values for $T W-F L$ were close to those for $E W-F L$, as follows, for males and females respectively: $T W=$ $0.1034 F L^{2.4832}\left(\mathrm{R}^{2}=0.785\right) T W=0.0972 F L^{2.4889}$ $\left(\mathrm{R}^{2}=0.867\right)$.

Of the 101 females examined, $15 \%$ were immature (Fig. 4A), 16\% were maturing (9\% in early maturation (Fig. 4B1), and 7\% in late maturation (Fig. 4B2)), 23\% mature (Fig. 4C), 4\% spent (Fig. 4D) and 42\% resting (Fig. 4E). Females in late maturation were found only from October to March, whilst resting females were more frequent in June and July (Fig. 5).

Unlike the females, all males were found with spermatozoa stored in the seminiferous tubules, and were therefore considered as sexually mature.

The monthly mean gonad index of both males and females was lowest in June and July (Fig. 6). The highest mean values for females were recorded in January, March, August and September, and for males in March, August, September and December. Female size at first sexual maturity $\left(\mathrm{L}_{50}\right)$ was estimated at $14.6 \mathrm{~cm}$ (Fig. 7), according to the following equation:

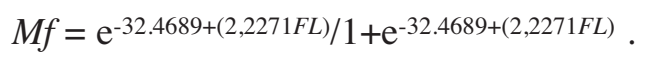

Based on this size, only $7 \%$ of all females sampled were juveniles.

The frequency distribution of oocyte diameter showed a mode for all stages at around $40 \mu \mathrm{m}$, which represents the oocytes at the perinucleolus stage. As oocyte development progresses, new modes from batches of larger oocytes become visible, together with the $40 \mu \mathrm{m}$ oocyte class (Fig. 8). This pattern of ovarian development indicates that spawning is synchronous, with the oocytes ripening in more than two groups. Therefore, it is characterized as a batch spawning. 

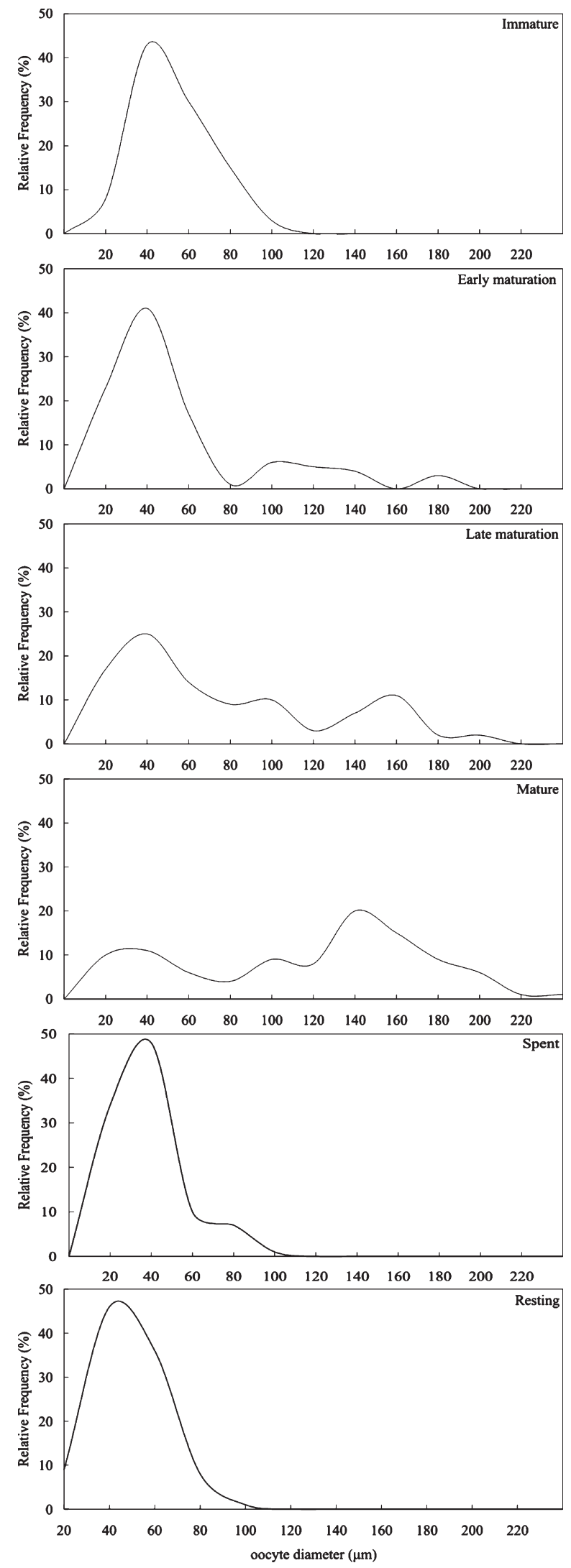

FIG. 8. - Frequency distribution of oocyte diameter of female $H$. adscensionis at six different sexual stages.
The total fecundity of 12 ripe gonads ranged from 56274 to 249863 oocytes, with a mean of 148570 oocytes per ripe gonad. Total fecundity $(T F)$ was linearly related to the weight of the ovary $(O W)$, as follows: $T F=3.30490 W-3.6519\left(\mathrm{R}^{2}=0.951\right)$.

\section{DISCUSSION}

The sex ratio close to $1: 1$ is the expected result for an equilibrium population, since the number of males and females at birth is generally the same (Santos, 1978; Aguilar and Malpica, 1993). Nevertheless, according to Vazzoler (1996) and Wu et al. (2001), this ratio might differ from 1:1 due to different growth rates, mortality rates and longevity for each sex, sexual inversion and migration to spawning grounds.

The fork-length frequency distribution does not express the real size structure of the population due to the bias from fishing gear selectivity and spatial segregation. Nevertheless, the small number of juvenile specimens in the sample (about 7\%) suggests that the fishery is mainly targeting adults, which is positive for the sustainability of the fishery. The TW-EW relationship is important for estimating live weight from landed weight, as well as assessing the most adequate selling price for the whole and eviscerated fish.

Although the length-weight relationship is commonly drawn from the total weight and fork length (Ricker, 1975), using eviscerated weight, as in the present paper, allows a more accurate estimate, since the maturity stage (gonad weight) and stomach contents may strongly influence the total weight. Nevertheless, $T W-F L$ was also estimated in order to allow comparisons with other authors (Table 2).

This geographical variation might be related to the nutritional condition of the fish examined, due to prey availability and predation resulting from different environmental conditions and fish behaviour. However, it might also be influenced by the size and length frequency distribution of the sample treated in the different studies.

The seasonal changes in distribution of the different sexual stages associated with the variation of the monthly mean gonad index, with the lowest values for both males and females being recorded in June and resting after a peak reproduction in May, suggests lower sexual activity during this time of the year, which coincides with winter time. Since $H$. 
TABLE 2. - Different values of $\theta$ found by various authors for $H$. adscensionis, indicating sex, length, sample size and site.

\begin{tabular}{lcccccl}
\hline 1 & Sex & Length $(\mathrm{cm})$ & Length type & No. & Localization & Reference \\
\hline 2.120 & unsexed & $17.1-23.2$ & SL & 26 & Gulf of Salamanca, (Colombia) & Garcia et al. (1998) \\
2.660 & unsexed & $14.0-19.0$ & FL & & Jamaica & Wyatt (1983) \\
3.000 & unsexed & $19.0-38.0$ & FL & 108 & Southern Florida (USA) & Bohnsack and Harper (1988) \\
3.000 & unsexed & $16.0-25.0$ & FL & 187 & St. Croix (US Virgin Is) & Bohnsack and Harper (1988) \\
3.000 & unsexed & $18.0-27.0$ & FL & 98 & St. Thomas/St. John (US Virgin Is) & Bohnsack and Harper (1988) \\
3.170 & unsexed & & FL & & Northeast coast of Brazil & Nomura (1965)
\end{tabular}

$\overline{\mathrm{SL}}=$ standard length: The measurement from the tip of the snout to the posterior end of the vertebral column. FL: Fork Length: The measurement from the tip of the snout to the posterior end of the middle caudal rays.

adscensionis is a tropical species, continuous reproductive activity throughout the year could be expected, as suggested by the presence of mature females throughout the year (Fig. 5). Several environmental factors, however, might contribute to lower sexual activity during winter, such as lower temperatures, salinity, and photoperiod, as well as higher turbidity (Murphy and Taylor, 1989). For Dascyllus albisella Gill, for instance, Danilowicz (1995) reported a strong intensification of reproductive activity, as a result of a sudden rise in sea water temperature. The small number of spent females is probably related to the relatively short time females spend in this stage.

For the Holocentridae Sargocentron rubrum from the Mediterranean Sea, Golani and Ben-Tuvia (1985) reported a short spawning season from July to August. Galzin (1987), studying the gonosomatic index of the species Sargocentron microstoma in French Polynesia, suggested a spawning season from December to January. The occurrence of spawning in the warmer months is reported by Munro et al. (1973) and Wyatt (1983) for the Holocentridae species from the Caribbean.

The fork length of the largest specimen examined $(21.5 \mathrm{~cm})$ was close to the $\mathrm{L}_{\infty}$ found by Wyatt (1983), for specimens caught off Jamaica $(26.5 \mathrm{~cm})$. Size at first sexual maturity was also very similar between the two regions (14.6 cm off Pernambuco, $14.5 \mathrm{~cm}$ off Jamaica), and was, in the present case, significantly smaller than the most caught size class. This is beneficial for the sustainability of the fishery. The diameter frequency distribution of the oocytes was also close to that described by Wyatt (1983), again pointing to a large similarity between the reproductive biology of the species in both hemispheres of the western Atlantic.

The strong relationship between ovarian weight and absolute fecundity $\left(\mathrm{R}^{2}=0.951\right)$, allows the late to be estimated from the weight of the ovary (Delahunty and Vlaming, 1980). Bagenal and
Braum (1978) noted that fecundity is commonly proportional to the size of the fish. For H. adscensionis off Pernambuco, however, the increase in ovarian weight with size seems to be more related to the higher proportion of specimens in a more advanced sexual stage than to larger ovaries. A similar trend was found by Johns and Miranda (1997), studying Dorosoma cepedianum (Lesueur) off the Mississippi.

\section{REFERENCES}

Aguilar, E.T.A. and Z.G.C. Malpica. - 1993. Biologia Pesqueira. $1^{\text {a }}$ edição. Editora Libertad, Trujilo.

Bagenal, T.B. and E. Braum. - 1978. Eggs and early life history. In: T.B. Bagenal (ed.), Methods for the assessment of fish production in freshwaters, pp. 165-201. Blackwell Scientific Publications, London.

Beets, J. - 1997. Effects of a predatory fish on the recruitment and abundance of Caribbean coral reef fishes. Mar. Ecol. Progr. Ser., 148: 11-21.

Ben-Tuvia, A. - 1990. Holocentridae. In: J.C. Quéro, J.C. Hureau, C. Karrer, A. Post and L. Saldanha (eds.), Check-list of the fishes of the eastern tropical Atlantic (CLOFETA), Vol. 2: pp. 627628. JNICT, Lisbon; SEI and UNESCO, Paris.

Bohnsack, J.A. and D.E. Harper. - 1988. Length-weight relationships of selected marine reef fishes from the southeastern United States and the Caribbean. NOAA Tech. Mem. NMFSSEFC-215.

Carlson, B.A. and A.H. Bass. - 2000. Sonic/Vocal Motor Pathways in Squirrelfish (Teleostei, Holocentridae). Brain Behav. Evol., 56: $14-28$.

Carvalho-Filho, A. - 1999. Peixes: costa brasileira. Ed. Melro, São Paulo.

Danilowicz, B.S. - 1995. The role of temperature in spawning of the damselfish Dascyllus albisella. Bull. Mar. Sci., 57: 624-636.

Delahunty, G. and V. deVlaming. - 1980. Seasonal relationships of ovary weight, liver weight and fat stores with body weight in the goldfish (Carassius auratus L.). J. Fish Biol., 16: 5-13.

Galzin, R. - 1987. Potential fisheries yield of a Moorea fringing reef (French Polynesia) by the analysis of three dominant fishes. Atoll Res. Bull., 305: 1-22.

García, C.B., L.O. Duarte, N. Sandoval, D. Von Schiller, G. Melo and P. Navajas. - 1998. Length-weight relationships of demersal fishes form the Gulf of Salamanca, Colombia. Fishbyte, 21: 30-32.

Greenfield, D.W. - 1981. Holocentridae. In: W. Fischer, G. Bianchi and W.B. Scott (eds.) FAO species identification sheets for fishery purposes. Eastern Central Atlantic; fishing areas Vol. 2: 34, 47 (in part). Department of Fisheries and Oceans Canada and FAO.

Golani, D. and A. Ben-Tuvia. - 1985. The biology of the IndoPacific squirrelfish, Sargocentron rubrum (Forsskål), a Suez 
Canal migrant to the eastern Mediterranean. J. Fish Biol., 27: 249-258.

Johns, G.D. and L.E. Miranda. - 1997. Ovarian weight as an index of fecundity, maturity, and spawning periodicity. J. Fish Biol., 50: $150-156$

Marza, V.D. - 1938. Histophysiologie de l'Ovogenèse. Herman et Cie, Paris.

Mendes, P.P. - 1999. Estatística aplicada à Aqüicultura. Ed. Bargaço, Recife-PE.

Munro, J.L., V.C. Gaut, R. Thompson and P.H. Reeson. - 1973. The spawning season of Caribbean reef fishes. J. Fish Biol., 5: 69-84.

Murphy, M.D. and R.G. Taylor. - 1989. Reproduction and growth of black drum, Pogonias cromis, in northeast Florida. Northeast Gulf Sci., 10: 127-137.

Nomura, H. - 1965. Length-weight tables of some fish species from Northeastern Brazil. Arq. Est. Biol. Mar. Univ. Fed. Ceará, 5(2): 103-105.

Ricker, W.E. - 1975. Computation and interpretation of biological statistics of fish populations. Bull. Fish. Res. Board Can., 191: $1-382$.

Robins, C.R. and G.C. Ray. - 1986. A field guide to Atlantic coast fishes of North America. Houghton Mifflin Company, Boston, U.S.A.

Santos, E.P. - 1978. Dinâmica de populações aplicada a pesca e pis- cicultura. Editora de Humanismo, Ciência e tecnologia "HUCITEC" LTDA. Editora da Universidade de São Paulo.

Schaeffer, M.B. and C.J. Orange. - 1956. Studies of the sexual development and spawning of yellowfin tuna (Neothunnus macropterus) and skipjack (Katsuwonus pelamis) in the three areas of the Eastern Pacific Ocean, by examination of gonads. Inter-Am. Trop. Tuna Com. Bull., 1(6): 281-302.

Thresher, R.E. - 1984. Reproduction in reef fishes. T.F.H. Publications, Inc. Ltd., Neptune City, New Jersey.

Vazzoler, A.E.A. de M. - 1996. Biologia da reproduççãão de peixes teleóósteos: teoria e pratica. EDUEM, Maringa.

Woods, L.P. and D.W. Greenfield. - 1978. Holocentridae. In: W. Fischer (ed.) FAO species identification sheets for fishery purposes. Western Central Atlantic (Fishing Area 31). Vol. 3. FAO, Rome.

Wu, CC., W.C. Su and T. Kawasaki. - 2001. Reproductive biology of the dolphin fish Coriphaena hippurus on the east coast of Taiwan. Fish. Sci. Japan, 67: 784-793.

Wyatt, J.R. - 1983. The biology, ecology and bionomics of the squirrelfishes, Holocentridae. In: J.L. Munro (ed.) Caribbean coral reef fishery resources, pp. 50-58. ICLARM Stud. Rev. 7.

Scient. ed. M. Harmelin-Vivien.

Received October 19, 2006. Accepted June 1, 2007.

Published online October 17, 2007. 